\title{
WAR: DEMOCRACY'S LENGTHENED HAND
}

\author{
Andrian Willyan Djaja ${ }^{*}$ \\ ${ }^{1}$ Marine Geological Institute, Bandung, Indonesia
}

\section{ARTICLE INFO}

\section{Keywords}

Democracy, War,

Politics, Ideology

\section{*Correspondence \\ asepwong@yahoo.com}

\section{Article History}

Received 11 November 2018

Accepted 14 January 2019

Published online 31 January 2019

\section{ABSTRACT}

Democracy and monarchy are often considered counterparts, and people tend to choose the free-will-conserving democracy rather than the stiff monarchy. The United States of America gives all they have to spread democracy to the world, even using militaristic way. It is obvious that America forces their democracy to be played by countries of the world, through the war as a way, and politics as another way. In short, war is just a tool for America to spread democracy to the whole world.

Demokrasi dan monarki sering dianggap bertentangan, dan orang-orang cenderung memilih demokrasi yang mempertahankan kebebasan memilih daripada monarki yang kaku. Amerika Serikat berupaya keras untuk menyebarkan demokrasi ke seluruh dunia, bahkan menggunakan cara militer. jelas bahwa Amerika memaksakan demokrasi mereka untuk digunakan negara-negara di seluruh dunia, melalui perang sebagai salah satu cara, dan politik sebagai cara lainnya. Singkatnya, perang hanyalah salah satu cara yang digunakan Amerika untuk menyebarkan demokrasi ke seluruh dunia.

\section{INTRODUCTION}

Aristoteles in his work Politics described three government systems and their perversions: monarchy (perversion: dictatorship), oligarchy (perversion: aristocracy), and constitutional government (perversion: democracy) (Aristotle, 1943). Here democracy is described as a governmental system which follows the majority to make decisions regarding many kinds of governmental problems. Aristoteles himself mentions democracy as a perversion. It is a divergence from a constitutional system which takes decisions from certain constitution made by the people which work as a basis for majority voice.

Democracy is often described as a counterpart from monarchy or dictatorship due to the nature of voice used in decision making. Monarchy uses a single ruler - and automatically, single voice - in making the government's decision and rules; the ruler's voice. Democracy claimed to use majority - in assumption, people's - voice in deciding rules for internal and external affairs. Through these definitions, democracy often assumed as an opposite of monarchy and dictatorship, although in practice both come with very little difference. Democracy often reduced into oligarchical or aristocracy government because of Its concept of people's representative (usually in the form of people's council).

Considered as monarchy's opposite, democracy is often seen as a peaceful governmental system, also because of it is judged nature as the government of majority which able to settle disputes between people, which then resulting peace (Stavridis, 2018). However, history proves that this is not entirely true.

An example that comes by reading history texts is that democracy is an idea that must be fought over for, not comes by itself. In other words, democracy must be spread over to the world by any means possible - books, writings, scientific papers, speeches, electronic media, even war. Yes, war. Invasion of a country can be justified by or as spreading democracy and erasing dictatorship, although, in reality, it was just an invasion.

Democracy's involvement in war can be traced back to pre-World War II, when German rose into Third Reich and attract the world, including Britain, France, and the United States itself by its massive military power and principality taken from Hitler's work Mein Kampf. The United States initially holds back from the commotion in Europe by applying isolation policy, saw this as an opportunity to abandon their policy for a bigger purpose.

Conflicting states in Europe: Germany (dictatorship), Britain (kingdom), Russia (formerly kingdom), France (formerly kingdom), Italy (dictatorship), and other states are all based on monarchical government, while Japan in Asia is an empire bent on domination in Asia. The United States saw this as an opportunity to introduce - and force - democracy to the world. In short, the United States gave the world two options: monarchy or democracy (Donovan, 1970). These options stick to the minds of people of the world until now, identical with the 'either you're with us or with terrorist' statement; an old version of 'stick and carrot' play.

In the aftermath of World War II, United States rises as champion, further solidifying grounds for democracy, also symbolizes that monarchy will be crushed by the will of the people. This also gives the United States a solid ground for strengthening its

(C) 2019 by the authors; Association of Indonesian Moslem Scholar, Hannover, Germany. This is an Open Access article distributed under the terms of the Creative Commons Attribution-ShareAlike 4.0 International License. (https://creativecommons.org/licenses/by-sa/4.0/), which permits unrestricted use, distribution, and reproduction in any medium, provided the original work is properly cited. 
military strength for 'democracy purpose'. The situation is an opportunity that was used by the United States to dominate the world in capitalism. The United States is then - and now - known as the 'arsenal of democracy', and challenging the United States means war to democracy.

If we take a look at the end of World War II, Japan was destroyed by two nuclear bombings at Hiroshima and Nagasaki. Millions died, also traumatized Japanese until today. Such the price for democracy and the US never care about the consequences. Nuclear arsenal then became a tool for deterrence to the world, and the world since then feared the United States. The obedience to democracy was based on fear, leading to world domination.

The fight for democracy continues. Cold War starts directly after World War II, only this time the Western Block (represented by the United States and carries capitalism) against Eastern Block (represented by the Soviet Union and carried socialism). Both carrying each version of democracy. This is another way to look at war which plays important role in spreading democracy (Cross, 2006).

\section{RESEARCH METHODS}

This letter was based on literature reading through classic books, namely Militarism, U.S.A., and Politics (written by Aristoteles), also recent books, namely The Encyclopedia of Warfare and The Cold War Experience, and also recent printed media namely Time magazine. The analysis was done based on the facts collected from the literature. The conclusion was decided after the analysis was completed.

\section{RESULTS AND DISCUSSIONS}

We are currently able to see the inconsistency in democracy. In Western terms, democracy is a condition where people are free to speak, act, and also free from religion. In Eastern terms, democracy is interpreted as giving people's rights to land, earth resources, also basic rights, returned to the people. So there are two definitions of democracy. The only consistency in a democracy is that these purposes can be fought over through war.

Vietnam saw these events. A 10-years war engulfs the nation and ended with United States' loss. Several years before, the Korean War destroyed both North and South Korea as a result of the war between the United States and the proxy of the Soviet Union. After World War II, Germany was divided into two nations: West Germany and East Germany. The city of Berlin was also divided into West Berlin and East Berlin (Friedman, 2005).

Recent development in Asia also involves the United States. China, emerged as a new power in Asia, challenged the United States directly using its advances in military technology, also announced itself as a socialist state. China's actions captured America's attention and the United States lock their eyes into China at every time they can. China, in the eyes of American, is the enemy of America's democracy.

A similar situation happened in North Korea. Kim Jong Un dictatorship and North Korea's threat to South Korea lured America's involvement. Socialist by history, it is only natural that North Korea is seen by Americans as a common enemy since their history is also as enemies since the Korean War.

In recent times, the War Against Terrorism is another fight for democracy. It is a war to spread United States' stronghold to the world, especially the Middle East. Followed shortly by invasion to Iraq, then Libya, Syria, and currently battle against ISIS. The Arsenal of Democracy endlessly wages war in the whole world.

If we look at the whole historical picture, at least in the $20^{\text {th }}$ century, we see that very few times since the beginning of the century that is not filled with war. The United States constantly produced weapons and sell it or use it in the whole world in many battlefields, using many kinds of reasons; terrorists, dictators, weapons of mass destruction, etc.

\subsection{Judging Uncle Sam}

At this point, we start to judge the United States. Democracy, according to Aristoteles, came from constitutional government system, which is a governmental system based on the constitution. When constitution held by the people as the main reference in daily governmental activities, the people turns into the one that actually runs the government, resulting in a democracy which Aristoteles said as a perversion of the constitutional system.

Constitution, however, is different from one country to another. This, in the end, will produce different will-of-the-people, which results in different rules of democracy from one country to another. Western World, however, forces their democracy to developing countries such as Indonesia. An example of such act is lesbian, gay, bisexual, and transgender (LGBT) 'rights'. Western figures came to Indonesia often to promote LGBT in Indonesia; or at least, they are LGBT supporters, while LGBT itself does not have any root in Indonesia. Such visit, for example, British Prime Minister, David Cameron, who is an LGBT supporter.

Such intervention is nothing new for the West. In fact, along with Western military capabilities which also works as a tool for deterrence, it is an act of force by Western countries to other countries, or in short, oppression. From the example above, LGBT is often forced using democracy, however its nothing more but an act of force. The question is: what if the people of the country does not want to accept LGBT? If people do not want LGBT, then in theory, democratically, LGBT will not be accepted in that country. That is how democracy should work, at least in theory. The visit by Cameron has proven to be a form in intervention by Western countries to force Indonesia to accept lesbian, gay, bisexual, and transgender communities.

However, it is quite the contrary for Saudi Arabia. Saudi is a monarchical country, governed by king and princes, but the United States does not force democracy in the oil-rich country. In fact, Saudi is America's close ally in the Middle East, as seen by many cooperation in military and economic sectors. The United States never - until now - forces democracy to Saudi Arabia, while Saudi Arabia is well-known as a country with the monarchical governmental system. By Aristoteles' definition, the monarchy is not a constitutional system, neither democracy as well.

The same goes for the United Kingdom which is a kingdom for centuries and definitely a country running a monarchical system. Has America ever ask them to leave their monarchical system and turn into the constitutional democratic system? Never until now. The on-and-off ally - and rival - of United States remains a monarchy.

The question now becomes: what is it the democracy the Americans so fond of? As mentioned above, they are freedoms; to speak, to take - or not taking - a religion, to act, and to think. Through these ideas, America is able to enter every country in the world and spread any actions, thoughts, lifestyles, trends, and anything they consider good, not what the people of the country 
consider good. LGBT, as mentioned above, is an example. In the end, the country will follow anything America throw at them, as already happened to Japan.

\subsection{Democracy's Forced Hand}

If conquering through ideas do not work, America will shift to military ways (Furniss, 1957). Threats, black campaigns, embargos, even military actions will be used. Preceding it all is deterrence using America's advanced military capabilities. Through fear, America demands obedience from the whole world, although not every country is willing to follow America's wish. Title 10, Section 3062 of the United States Code mentioned in part that the United States Congress gives a mission to the United States Army with a duality. The first segment is the preservation of peace and security by repelling and defeating aggression. The second segment is "overcoming any nations responsible for aggressive acts that imperil the peace and security of the United States". This part of US Army mission makes aggression recognizable with acts such other state's border breaching or hostile missile to a neighboring country (Pizer, 1969).

This second part of the US Army's mission is what leads to oppression in the name of democracy. The sentence 'aggressive acts that imperil the peace and security of the United States' was not defined clearly. What kind of act considered an aggressive act? Is China's or North Korea's military capability improvement considered as an aggressive act? How could an act be considered imperil to the United States? If Indonesia or other Muslim countries increase their military capabilities significantly, will this be considered to imperil the US?

It is now the US' political acts can be understood by many, for example, America's several years quarrel with Iran or recent commotions with North Korea and China. Even with rivals like Russia or the United Kingdom, America may use political moves against them, such selling latest technology like F-35 Lightning II or cutting diplomatic relationship. However, with Iran, America is not playing nice but goes directly to threats and black campaigns. The same happened to China and North Korea. Although so far there are no indications that the United States will mix it up to these countries, one of the options of how to deal with them is militaristic.

While Islam's jihad is often blamed as a form of oppression, the agents of democracy also force the whole world to accept democracy. Chomsky has mentioned, "Why would a pirate is called a pirate simply because he robs in one ocean, while an emperor is called an emperor because he spreads the war to the whole world?" (Chomsky, 2016). This analogy pictures our reality right now. Anyone who goes to war while screaming Islam will be called a terrorist, while the United States never takes the blame over invading another country. Clearly, it is the war for democracy that is a way of oppression.

\section{CONCLUSION}

War is now can be seen as the Arsenal of Democracy's way to force democracy they offer to be taken by the whole world. In other words, democracy is spread using war as a tool, besides using scholars, books, writings, television shows, movies, and many more. The Arsenal of Democracy continuously produce weapons for their own political intention, and not even hesitated to use it while barricading other countries - especially Muslim countries - to produce their own weapons. We may conclude now that democracy does not arise naturally but actually forced through well-coordinated political movements - such as war - by Western countries.

\section{References}

Aristotle. (1943). The Politics of Aristotle. New York, NY: The Modern Library. Chomsky, N. (2016). Pirates and Emperors. London. UK: Pluto Press.

Cross, R. (2006). The Encyclopedia of Warfare. New York, NY: Barnes and Noble.

Donovan, J. A. (1970) Militarism, U.S.A. New York; NY: Praeger.

Friedman, N. (2005). The Cold War Experience. London, UK: Carlton Books.

Furniss, Jr., E. S. (1957). American Military Policy. New York, NY: Rinehart and Co.

Pizer, V. (1969). The United States Army. New York, NY: Praeger.

Stavridis, J. (2018). Democracy Will Prevail. Time Asia, 192(3), 32-39. 